\title{
Cause-Related Marketing in the Fashion Industry: The Role of Consumer Identification
}

\author{
Ji Young Lee ${ }^{\dagger}$ and Kim K. P. Johnson ${ }^{1)}$ \\ Fashion \& Textiles, State University of New York at Oneonta; New York, USA \\ ${ }^{1)}$ Retail Merchandising Program, University of Minnesota; Minnesota, USA
}

\begin{abstract}
Customer-company (C-C) identification is the perceived fit between the identities of a consumer and an organization. If a consumer identifies with a company that places a high priority on being socially responsible, a consumer who also values social responsibility may support and patronize that business because of the link between something that is important to both them and the company. Because $\mathrm{C}-\mathrm{C}$ identification may explain the success of cause-related marketing $(\mathrm{CRM})$ in the fashion industry, we investigated the effect of an image resulting from CRM on ratings of brand attributes (e.g., distinctiveness, credibility, attractiveness), identification with the brand, attitude toward the brand, and customer loyalty. Participants also responded to open-ended questions reflecting their rationale for their ratings of brand attributes. Data were collected from a convenience sample of undergraduates $(n=228)$ enrolled at Midwestern University in the U.S. Structural equation modeling revealed that as ratings of the social responsibility of the cause-related marketing effort increased so did perceptions of the brand's distinctiveness, credibility, and attractiveness. Participants identified with a brand when they rated the brand as attractive. Participants' identification with a brand had a significant impact on attitudes toward the brand and customer loyalty (e.g., purchase intention, willingness to spread positive word-of-mouth). Content analyses of open-ended responses supported the idea that brand images stemming from CRM exert an important influence on consumer's ratings of brand attributes. Fashion marketers interested in cause-related marketing will find success with efforts that increase customer identification.
\end{abstract}

Key words : cause-related marketing, corporate social responsibility, customer-company identification, customer loyalty

\section{Introduction}

Companies employ corporate social responsibility (CSR) strategies as a tool to communicate with their target consumers. Corporate social responsibility includes plans and actions that appear to advance the social good and go beyond furthering the interests of a firm (McWilliams \& Siegel, 2001). In general, consumer response to CSR strategies has been positive (Kim \& Sung, 2011).

Conceptually, CSR consists of four subcomponents: economics, law, ethics, and philanthropy (Carroll, 1991). Regarding these factors, CSR refers to making a profit, obeying the law, being ethical, and being a good corporate citizen. As types of CSR, companies spend great sums of money each year on corporate philanthropy, sponsorships, and cause-related marketing (Cornwell \& Coote, 2005). Among the CSR types, cause-related marketing (CRM) is a specific marketing activity in which the company promises its consumers to donate company resources to a worthy cause (Van den Brink et al., 2006).

Several fashion brands have adopted CRM strategies resulting in

$\dagger$ Corresponding author; Ji Young Lee

Tel. +1-607-436-2144, Fax. +1-607-436-2051

E-mail: JiYoung.Lee@oneonta.edu positive consumer response (Sen \& Bhattacharya, 2001). For example, the "Red campaign" entailed several fashion brands (e.g., NIKE, Gap, Converse) joining efforts to raise money to assist AIDS prevention campaigns in Africa. Estee Lauder, a US-based cosmetics brand, is involved in the woman's breast cancer awareness campaign through "Pink Ribbons", and develops a special product line for this campaign (e.g., Pink Ribbon lip set collection). The internationally recognized breast cancer organization, "Susan G. Komen for the Cure", is another example of the use of CRM in the fashion industry (Hyllegard et al., 2010). Several fashion brands (e.g., Michael Kors, Anne Klein, St. John Knits) have partnered with the cancer organization to raise money through the sale of specific products (e.g., pink-ribbon T-shirts). The profits from their efforts provide medical services to women diagnosed with breast cancer and support research for a cure (Hyllegard et al., 2010).

Companies can benefit from CRM, through improved brand image (Polonsky \& Speed, 2001), generating positive consumer brand attitudes (Barone et al., 2007), and increasing consumers' purchase intentions (Andrews et al., 2014). Consumers can also benefit from CRM. Patronizing a business that they believe has values that are aligned with their own, consumer satisfaction with that brand and its products can be increased. Additionally, consumer support of brands that engage in CRM may be yet another 
method of consumer differentiation (Curra's-Pe'rez et al., 2009).

Despite consumers' positive response toward companies that engage in CSR practices, few researchers have identified the mechanisms that underlie their responses (Becker-Olsen \& Hill 2006; Bign-Alcaiz et al., 2010). One possible cause for the positive consumer response to CRM is customer-company identification (BignAlcaiz et al., 2010; Marn \& Ruiz, 2007). Customer-company (C-C) identification refers to the perceived correspondence between the identity of a consumer and that of an organization (Bergami \& Bagozzi, 2000; Bhattacharya \& Sen, 2003). If a consumer identifies with a company or a brand and that brand places a high priority on being socially responsible, a consumer who values social responsibility may want to support and patronize that business because of the perceived connection between something that is important to their own identity and to that of the identity of the business. In addition, if consumers feel a cognitive connection or similarity between their identity/personality and a brand's identity/ personality, they may connect with a company because they can maintain a stable sense of self over time (Kunda, 1999). In support of this line of reasoning is research by Bign-Alcaiz et al.(2010) who found that customer-company identification was a powerful cognitive connection that motivated consumer's purchase intentions. Lee and Shin(2011) also noted that consumers evaluate a company's CSR efforts favorably if they believe their own values or interests are similar.

Because C-C identification may play a key role in explaining the success of the use of CRM in the fashion industry, our research purpose was to investigate the effect of a brand's cause-related marketing on C-C identification and consumer's response to the brand. Specifically, we investigated how the CSR image resulting from CRM influences consumer's perception of brand distinctiveness and credibility. Next, we examined how consumer's perception of brand distinctiveness and credibility influence their perception of brand attractiveness. Then, we assessed how perception of brand attractiveness influences C-C identification. Lastly, the effect of C$\mathrm{C}$ identification on consumer's attitude toward the brand and on their loyalty was examined. We also tested the effect of consumer's attitude toward the brand on customer loyalty. Finally, we identified a range of underlying reasons for consumer's reactions to a brand that engaged in CRM (e.g., brand distinctiveness, brand credibility, brand attractiveness).

\section{Literature Review}

\subsection{Conceptual Framework}

Curra's-Pe'rez et al.(2009)'s conceptual model of consumer identification with a socially responsible company framed our research. This conceptual model proposes that $\mathrm{C}-\mathrm{C}$ identification is a result of brand attractiveness. Brand attractiveness results from consumer's perceptions of the brand's prestige, distinctiveness, and coherence as impacted by the CSR image of the brand. This model also suggests that CSR-based C-C identification generates purchase intention directly and indirectly through positive attitudes toward the brand.

Brand coherence, defined as a consistent brand identity, and brand prestige were excluded from our research model because in Curra's-Pe'rez et al.(2009)'s original research, the researchers assessed consumer's ideas concerning known brands. Their use of existing brands with clear identities and prestige levels enabled them to operationalize these concepts. In contrast, we utilized a hypothetical brand to control for the influence of previous opinions about a brand (i.e., brand coherence, brand prestige) and the possible confounding impact these aspects of a brand could have with a CRM effort. However, we included brand credibility to our research model as an outcome of CSR image, as brand credibility can be generated by the perceived CSR image of a brand (Hong \& Rim, 2010).

\subsection{Antecedents of $\mathrm{C}-\mathrm{C}$ Identification}

As noted, there are four antecedents to C-C identification: CSR image, perceived brand distinctiveness, brand credibility, and brand attractiveness. When a company is involved in a CSR initiative, consumers may perceive the company as altruistic. CSR image refers to consumer's perception of the corporate social responsibility of a business organization (Curra's-Pe'rez et al., 2009). If this image is positive, it may lead to favorable evaluations of the company (Nan \& Heo, 2007) (e.g., brand distinctiveness) as well as to trust in the company (Groth, 2005), and subsequently to identification with a brand (Curra's-Pe'rez et al., 2009). Brand distinctiveness is the degree to which a consumer believes that a particular brand is different from other brands (Zhou \& Nakamoto, 2007). According to Bloom et al.(2012), one means to make a brand different or unique relative to its competitors is to engage in CSR.

Brand credibility is "the believability of the information contained in a brand, which requires that consumers perceive that the brand have the ability (i.e., expertise) and willingness (i.e., trustworthiness) to continuously deliver what has been promised" (Tlin $\&$ Swait, 2004). Hong and Rim(2010) found that there was a positive association between consumer trust and businesses being socially responsible such that consumers trusted a company that they perceived as being socially responsible.

Consumer's perceived brand distinctiveness and credibility is linked to brand attractiveness, the degree to which individuals perceive a brand as sufficiently appealing (Curra's-Pe'rez et al., 2009). 
The more consumers perceive a brand's identity as distinct and credible, the more they perceive the brand as attractive. The more consumers perceive the brand as attractive, the more they tend to identify with a company (i.e., greater C-C identification) (Bergami \& Bagozzi, 2000).

\subsection{Outcomes of C-C Identification}

Customer-company relationship causes consumers to align with the organization through forming positive attitudes toward the brand and positive behavior toward the brand (e.g., purchasing). When consumers identify with the company, they demonstrate loyalty relative to the company including being willing to try new products, spreading positive word-of mouth about the company, and being resistant to negative information associated with a company (Bhattacharya \& Sen, 2003).

Researchers have investigated the outcomes of consumer's identification with a socially responsible brand. Cornwell and Coote (2005) examined the effect of corporate's sponsorship of a cause on consumer response to the company. These researchers found that consumer's identification with a non-profit organization (NPO) mediated the relationship between the antecedents studied (i.e., perceived prestige of a NPO, consumer's affiliation with a NPO, consumer's motivation to support a cause) and consumer's willingness to purchase products from the NPO sponsoring firm. Similarly, the result of Bign-Alcaiz et al.(2010)'s study revealed that insurance (MapFre) and personal hygiene company's (Dove) involvement in CRM resulted in consumer's positive perceptions concerning these brands, identification with the brand, and product purchase intentions.

Subsequently, Lii et al.(2011) examined the effect of three types of corporate social responsibility initiatives (e.g., philanthropy, sponsorship, cause-related marketing) on undergraduate consumer's perceptions of the credibility of a social cause campaign, attitudes toward the sponsoring brand, subsequent extra-role behaviors (e.g., spreading positive word-of-mouth), and repurchase intention. The researchers also examined the moderating effect of consumer's psychological distance with the brand. The relationship between all three types of the CSR initiatives, perceived credibility of the campaign, and attitudes toward the brand were significant when participants perceived the brand as having low psychological distance. Put another way, CSR initiatives had a positive influence on consumer's attitudes toward the brand when consumers thought that the company had values similar to their own.

Within the context of fashion industry, Hyllegard et al.(2010) examined the impact of a specific fashion brand (Seven for all mankind) using CRM-focused advertising on Gen Y consumer's attitudes toward the apparel brand and purchase intentions. If the young consumers rated the CRM favorably, they indicated positive attitudes toward a brand featuring a cause-related message in its advertising. Also, the consumer's involvement in social causes (e.g., participation in a breast cancer marathon) had an impact on their purchase intention.

\subsection{Hypotheses}

Drawing from Curra's-Pe'rez et al.(2009)'s model of consumer identification with a socially responsible company and the extant literature, the following hypotheses were formulated for application to fashion brands.

H1. The CSR image of a brand influences brand distinctiveness.

H2. The CSR image of a brand influences brand credibility.

H3. Brand distinctiveness influences brand attractiveness.

H4. Brand credibility influences brand attractiveness.

H5. Brand attractiveness influences customer-company (C-C) identification.

H6. C-C identification influences consumer's attitude toward the brand.

H7. C-C identification influences customer loyalty.

H8. Consumer's attitude toward the brand influences customer loyalty.

\section{Methods}

\subsection{Data Collection}

The study population was U.S. male and female consumers from age 18 to age 30 . Using non-probability sampling, data were collected from a convenience sample of undergraduates enrolled at

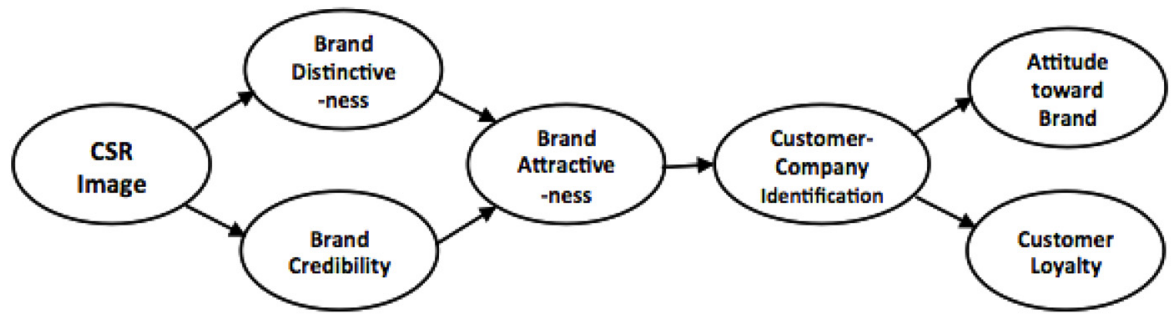

Fig. 1. Hypothesized model based on Curra's-Pe'rez et al.(2009)'s model of consumer identification with a socially responsible company. 
Midwestern University in the U.S. Young adult participants were considered appropriate because they tend to be more socially conscious and be responsive to cause-related marketing than other age groups (Burns et al., 2008; Hyllegard et al., 2010). Data were collected via a questionnaire posted online. Participants were asked to read a scenario describing a fashion brand that practiced CRM. Next, they responded to established measures of CSR image, brand distinctiveness, credibility, and attractiveness, C-C identification, attitudes toward the brand, and customer loyalty.

\subsection{Scenario Development and Pilot Test}

A scenario representing cause-related marketing was developed for the questionnaire. To develop a realistic stimulus, a scenario was developed based on existing empirical instances of an apparel brand's marketing practices. The scenario was reviewed by three individuals who have professional knowledge about apparel brand's marketing strategies. All reviewers agreed that the scenario reflected an existing fashion brand's CRM.

The scenario was developed based on the "RED" campaign. Under the RED campaign, apparel brands develop products designated as RED products. Customers buy RED products and a percentage of the monies generated are donated to the Global Fund, an organization to help African women and children affected by AIDS. Since it is possible that an authentic participant of the campaign could influence participant's responses, a fictitious brand name was used. The scenario informed participants that the fictitious fashion brand was a participant in the RED campaign.

A pilot study was conducted with a convenience sample of 50 undergraduates to ensure that participants could easily follow instructions, that the questions were easy to understand, and to estimate reliability of measures. Computed reliabilities of all the chosen measures reported adequate Cronbach's alpha coefficients (greater than 0.9).

\subsection{Questionnaire}

The questionnaire consisted of three sections. In the first part of the questionnaire, the scenario indicating the CRM activities of the fictitious fashion brand was provided. The second section included the established measures. Participants indicated their degree of agreement with statements included in the CSR image, brand distinctiveness, brand credibility, and brand attractiveness, C-C identification, attitude toward the brand, and customer loyalty measures using 7-point scales.

The measure of CSR image developed by Bhattacharya and Sen (2003) was utilized. The measure contains three items and assessed participant's perceptions of the degree the fictitious business was socially responsible. Sample items included " $[\mathrm{X}]$ gives back to society". Reported reliability of this measure was $a=.804$. Brand distinctiveness was measured using Bhattacharya and Sen(2003)'s three-item scale. A sample item was " $[\mathrm{X}]$ brand is different from the other brands in the sector". Reported reliability was $a=.841$.

A three-item measure developed by Newell and Goldsmith (2001) was used to assess brand credibility. Sample items included "I trust this brand". Reported reliability was $a=.920$. The measure of brand attractiveness was also adopted from Bhattacharya and Sen(2003)'s three-item scale. A sample item was "I like what [X] represents". The reported reliability was $a=.804$.

To investigate the underlying reasons for ratings of brand distinctiveness, credibility, and attractiveness, an open-ended question was provided after each scale. This question asked participants to "Please share what factors influenced your ratings of this brand's distinctiveness, credibility, and attractiveness".

Customer-company identification was measured with Bergami and Bagozzi(2000)'s five-item scale. Sample items included "The image I have of $[\mathrm{X}]$ overlaps with my self-image". Reported reliabilities of this scale was $a=.864$. This scale also included a diagram for participants to use to indicate the degree of coincidence they thought they had between their identity and the brand's identity (e.g., "The identity of this brand and mine are... 1 = Distant $7=$ Complete coincidence").

Attitude toward the fashion brand was measured using MacKenzie and Litz(1989)'s four-item measure. Each item was presented with its opposite (e.g., "1=bad - 7=good", "1=unfavorable $7=$ favorable"). Reported reliability was $a=.883$. Customer loyalty was assessed using Sirdeshmukh et al.(2002)'s measure. Sample items included "Will you do most of your future apparel shopping at this store?" and "Will you recommend this store to friends, neighbors, and relatives?" The reported reliability was $a=.843$.

The final section contained demographic questions. The questionnaire elicited questions about participants' characteristics (e.g., age, gender, ethnicity). Questions about the participant's previous or current experience with social causes (e.g., volunteering, fund raising) were also included.

\section{Results}

\subsection{Sample Characteristics}

Eliminating incomplete questionnaires resulted in a final convenience sample of 228 undergraduates. Participants were women $(n=204,89.5 \%)$ and men $(n=24,10.5 \%)$ whose ages ranged from 18 to $33(m=23.06)$. Most participants $(n=185,81.1 \%)$ were Caucasian. Other ethnicities included African-American $(n=25$, $11.0 \%$ ), Latino/Hispanic ( $n=10,4.4 \%)$, and Asian ( $n=8,3.5 \%)$. Participants were primarily majoring in fashion merchandising or 
design ( $n=190,83.3 \%$ ). The highest percentage of students was in their third year of study $(n=108,47.5 \%)$. Most participants ( $n=$ $140,61.4 \%$ ) responded that they had an experience with supporting a cause such as fundraising or purchasing a product from a brand sponsoring a cause (e.g., buying "TOMS Shoes").

\subsection{Hypotheses Testing and Discussion}

The results of confirmatory factor analysis showed that the measurements had acceptable construct validity and convergent validity. Item factor loadings from the confirmatory factor analysis completed on the data are presented in Table 1. Because all item factor loadings were greater than .50 , construct validity of measures were supported (Kim, 2007). Convergent validity is the extent that multiple measures of the same theoretical constructs are in agreement (Byrne, 1998). Convergent validity is supported by the following: (1) all loadings should be significant ( $p<.001)$, (2) the composite reliability for each construct should exceed the rec- ommended level of .70, and (3) the average variance extracted (AVE) for each construct should fulfill the recommended benchmark of .50 (Hair et al., 1988). All the factor loadings were significant $(p<.001)$, with composite reliabilities greater than 0.90 and AVEs all greater than .76 (Table 1).

Discriminant validity was established using the procedures outlined by Fornell and Laker (1981) and Hair et al.(1998). As evidence of discriminant validity, the squared correlations between constructs must be less than the AVE of each construct. Table 2 presents the correlations between the latent variables and the AVE of each construct. There was no case in which the square of a correlation between constructs was greater than the AVE of the constructs, providing evidence that the constructs within each of the pairs were different from each other.

Cronbach's alpha coefficients were higher than 0.905 , indicating that the reliabilities were acceptable for all measures (Table 3 ). The overall fit statistics $\left(\chi^{2} / \mathrm{df}=2.11 ; \mathrm{CFI}=.96 ; \mathrm{NNFI}=.96 ; \mathrm{IFI}=.96\right)$

Table 1. Measurement model evaluation

\begin{tabular}{|c|c|c|c|c|c|}
\hline Construct & Path coefficients & $\begin{array}{c}\text { Standardized Factor } \\
\text { Loading }\end{array}$ & t-value & $\begin{array}{l}{ }^{\mathrm{a}} \text { Composite } \\
\text { Reliability }\end{array}$ & ${ }^{\mathrm{b}} \mathrm{AVE}$ \\
\hline \multirow{3}{*}{ CSR image } & CSR image $\left(\xi_{1}\right) \rightarrow$ CSR1 & .94 & 18.67 & \multirow{3}{*}{.93} & \multirow{3}{*}{.81} \\
\hline & $\mathrm{CSR}$ image $\left(\xi_{1}\right) \rightarrow \mathrm{CSR} 2$ & .91 & 17.79 & & \\
\hline & CSR image $\left(\xi_{1}\right) \rightarrow$ CSR3 & .84 & 15.43 & & \\
\hline \multirow{3}{*}{ Brand distinctiveness } & Brand distinctiveness $\left(\xi_{2}\right) \rightarrow$ DIS1 & .88 & 16.86 & \multirow{3}{*}{.96} & \multirow{3}{*}{.89} \\
\hline & Brand distinctiveness $\left(\xi_{2}\right) \rightarrow$ DIS2 & .97 & 19.98 & & \\
\hline & Brand distinctiveness $\left(\xi_{2}\right) \rightarrow$ DIS3 & .97 & 20.10 & & \\
\hline \multirow{3}{*}{ Brand credibility } & Brand credibility $\left(\xi_{3}\right) \rightarrow$ CRE1 & .90 & 17.04 & \multirow{3}{*}{.90} & \multirow{3}{*}{.76} \\
\hline & Brand credibility $\left(\xi_{3}\right) \rightarrow$ CRE2 & .86 & 15.82 & & \\
\hline & Brand credibility $\left(\xi_{3}\right) \rightarrow$ CRE3 & .86 & 15.89 & & \\
\hline \multirow{3}{*}{ Brand attractiveness } & Brand attractiveness $\left(\xi_{4}\right) \rightarrow$ ATTR1 & .86 & 16.10 & \multirow{3}{*}{.95} & \multirow{3}{*}{.86} \\
\hline & Brand attractiveness $\left(\xi_{4}\right) \rightarrow$ ATTR2 & .96 & 19.32 & & \\
\hline & Brand attractiveness $\left(\xi_{4}\right) \rightarrow$ ATTR3 & .95 & 19.61 & & \\
\hline \multirow{5}{*}{$\mathrm{C}-\mathrm{C}$ identification } & $\mathrm{C}-\mathrm{C}$ identification $\left(\xi_{5}\right) \rightarrow \mathrm{CC} 1$ & .90 & 17.40 & \multirow{5}{*}{.96} & \multirow{5}{*}{.82} \\
\hline & $\mathrm{C}-\mathrm{C}$ identification $\left(\xi_{5}\right) \rightarrow \mathrm{CC} 2$ & .93 & 18.58 & & \\
\hline & $\mathrm{C}-\mathrm{C}$ identification $\left(\xi_{5}\right) \rightarrow \mathrm{CC} 3$ & .95 & 19.11 & & \\
\hline & $\mathrm{C}-\mathrm{C}$ identification $\left(\xi_{5}\right) \rightarrow \mathrm{CC} 4$ & .91 & 19.11 & & \\
\hline & $\mathrm{C}-\mathrm{C}$ identification $\left(\xi_{5}\right) \rightarrow \mathrm{CC} 5$ & .79 & 14.29 & & \\
\hline \multirow{4}{*}{$\begin{array}{l}\text { Attitude toward the } \\
\text { brand }\end{array}$} & Attitude toward the brand $\left(\xi_{6}\right) \rightarrow$ ATT1 & .90 & 17.39 & \multirow{4}{*}{.95} & \multirow{4}{*}{.83} \\
\hline & Attitude toward the brand $\left(\xi_{6}\right) \rightarrow$ ATT2 & .87 & 16.41 & & \\
\hline & Attitude toward the $\operatorname{brand}\left(\xi_{6}\right) \rightarrow$ ATT3 & .94 & 18.80 & & \\
\hline & Attitude toward the brand $\left(\xi_{6}\right) \rightarrow$ ATT4 & .95 & 19.01 & & \\
\hline \multirow{4}{*}{ Customer loyalty } & Customer loyalty $\left(\xi_{7}\right) \rightarrow$ CL1 & .94 & 18.76 & \multirow{4}{*}{.95} & \multirow{4}{*}{.87} \\
\hline & Customer loyalty $\left(\xi_{7}\right) \rightarrow$ CL2 & .96 & 19.64 & & \\
\hline & Customer loyalty $\left(\xi_{7}\right) \rightarrow$ CL3 & .90 & 17.38 & & \\
\hline & Customer loyalty $\left(\xi_{7}\right) \rightarrow$ CL4 & .86 & 16.06 & & \\
\hline
\end{tabular}

${ }^{a}$ Composite Reliability $=\left(\sum \text { standardized loading }\right)^{2} /\left(\sum \text { standardized loading }\right)^{2}+\sum$ measurement error

${ }^{\mathrm{b}}$ Average Variance Extracted $=\left(\sum \text { standardized loading }\right)^{2} / \sum$ (standardized loading $)^{2}+$ measurement error 
Table 2. Correlation matrix

\begin{tabular}{|c|c|c|c|c|c|c|c|}
\hline & 1 & 2 & 3 & 4 & 5 & 6 & 7 \\
\hline CSR image (\#1) & .81 & & & & & & \\
\hline Brand distinctiveness (\#2) & .70 & .89 & & & & & \\
\hline Brand credibility (\#3) & .55 & .53 & .76 & & & & \\
\hline Brand attractiveness (\#4) & .65 & .58 & .72 & .86 & & & \\
\hline C-C identification $(\# 5)$ & .39 & .33 & .51 & .57 & .82 & & \\
\hline Attitude toward the brand (\#6) & .49 & .41 & .59 & .74 & .56 & .83 & \\
\hline Customer loyalty (\#7) & .34 & .26 & .52 & .57 & .66 & .63 & .87 \\
\hline
\end{tabular}

Note: The average variance extracted (AVE) of each construct is shown on the diagonal. The square of a correlation between constructs is less than AVE of the constructs. This result supports discriminant validity across all constructs providing evidence that the constructs within each of the pairs are different from each other.

Table 3. Reliability of measures

\begin{tabular}{|c|c|c|}
\hline Construct & Items & Reliability \\
\hline CSR Image & $\begin{array}{l}\text { - This brand fulfills its social responsibilities. } \\
\text { - This brand acts in a socially responsible way. } \\
\text { - This brand gives back to society. }\end{array}$ & $a=.922$ \\
\hline Brand Distinctiveness & $\begin{array}{l}\text { - This brand is different from the rest of its competitors. } \\
\text { - This brand stands out from its competitors. } \\
\text { - This brand is different from the other brands in the sector. }\end{array}$ & $a=.958$ \\
\hline Brand Credibility & $\begin{array}{l}\text { - I think that this brand is credible. } \\
\text { - I think that this brand has an expertise. } \\
\text { - I trust this brand. }\end{array}$ & $a=.905$ \\
\hline Brand Attractiveness & $\begin{array}{l}\text { - I like what this brand represents. } \\
\text { - I think that this brand is an attractive brand. } \\
\text { - I like what this brand embodies. }\end{array}$ & $a=.944$ \\
\hline Customer-Company Identification & $\begin{array}{l}\text { - I am similar to what I think this brand represents. } \\
\text { - The image I have of this brand overlaps with my self-image. } \\
\text { - I am similar to how I perceive this brand. } \\
\text { - The way I am fits in with what I perceive of this brand. } \\
\text { - The identity of this brand and mine are... } \\
\text { A } \\
\text { F } \\
\text { F }\end{array}$ & $a=.957$ \\
\hline Attitudes Toward the Brand & $\begin{array}{l}\text { I think this brand is... } \\
\text { - Bad-good } \\
\text { - Negative-positive } \\
\text { - Unpleasant-pleasant } \\
\text { - Unfavorable-favorable }\end{array}$ & $a=.953$ \\
\hline Customer Loyalty & $\begin{array}{l}\text { How likely are you to... } \\
\text { - do most of your future shopping at this brand? } \\
\text { - recommend this brand to friends, neighbors, and relatives? } \\
\text { - use this brand the very next time you need to shop? } \\
\text { - spend more than } 50 \% \text { of your budget with this brand? }\end{array}$ & $a=.952$ \\
\hline
\end{tabular}

suggested that the measurement model had a good fit with the data. A structural analysis was conducted using the maximum likelihood estimation method. The measures of goodness of fit for the model were satisfactory $\left(\chi^{2} / d f=2.03, \mathrm{CFI}=.96, \mathrm{NNFI}=.96\right.$, 
Table 4. Structural model

\begin{tabular}{clcc}
\hline Fit Statistics & \multicolumn{1}{c}{ Path } & Estimate & t-value \\
\hline & H1: CSR image $\rightarrow$ Brand distinctiveness & $\beta=.851^{* * *}$ & 13.55 \\
& H2: CSR image $\rightarrow$ Brand credibility & $\beta=.826^{* * *}$ & 12.75 \\
$\chi^{2} / d f=2.03$ & H3: Brand distinctiveness $\rightarrow$ Brand attractiveness & $\beta=.165^{* *}$ & 2.96 \\
CFI $=.96$ & H4: Brand credibility $\rightarrow$ Brand attractiveness & $\beta=.803^{* * *}$ & 11.20 \\
NNFI $=.96$ & H5: Brand attractiveness $\rightarrow$ C-C identification & $\beta=.759^{* * *}$ & 12.90 \\
IFI $=.96$ & H6: C-C identification $\rightarrow$ Attitude toward the brand & $\beta=.349^{* * *}$ & 5.62 \\
RMSEA $=.067$ & H7: C-C identification $\rightarrow$ Customer loyalty & $\beta=.484^{* * *}$ & 7.89 \\
& H8: Attitude toward the brand $\rightarrow$ Customer loyalty & $\beta=.438^{* * *}$ & 6.98 \\
\hline
\end{tabular}

$\overline{* *} p<.01, * * * p<.001$

$\mathrm{IFI}=.96, \mathrm{RMSEA}=.067) . \mathrm{CSR}$ image of the brand positively influenced brand distinctiveness $(\beta=.851, p<.001)$ and credibility $(\beta=.826, p<.001)$. Brand distinctiveness $(\beta=.165, p<.01)$ and brand credibility $(\beta=.803, p<.001)$ positively influenced brand attractiveness. Participants rated a brand as distinctive, credible, and attractive if they rated the CRM effort of the brand as socially responsible. This result was consistent with Curra's-Pe'rez et al.(2009)'s finding that CSR image affects consumer's perception of a brand distinctiveness and brand attractiveness. This result also supported Hong and Rim(2010)'s finding that consumers trust a company if they view the company as socially responsible. Thus, $\mathrm{H} 1, \mathrm{H} 2, \mathrm{H} 3$, and $\mathrm{H} 4$ were supported.

Next, brand attractiveness had a positive influence on identification with the brand ( $\mathrm{C}-\mathrm{C}$ identification) $(\beta=.759$, $p<.001)$. The more attractive the rating of the brand, the more consumers indicated they identified with the brand. C-C identification then had a positive effect on consumer's attitude toward the brand $(\beta=.349, p<.001)$ and on customer loyalty $(\beta=.484$, $p<.001)$. There was also positive effect of consumer's attitude toward the brand on customer loyalty $(\beta=.438, p<.001)$. These results indicated that consumer's identification with a socially responsible company predicted their positive brand attitudes. Further, $\mathrm{C}-\mathrm{C}$ identification predicted intention to purchase a product from the brand, willingness to recommend the brand to others, and willingness to spend a significant portion of their budget on the brand's products. These results were consistent with the findings of previous researchers (Bign-Alcaiz et al., 2010; Cornwell \& Coote, 2005). Thus, H5, 6, 7, and 8 were supported (Table 4).

\subsection{Analysis of Open-ended Questions}

Participants' responses to the questions eliciting their rationale for their ratings of brand distinctiveness, credibility, and attractiveness were content analyzed. Because not all participants responded to these open-ended questions, the percentages of respondents reported are based on the number of responses rather than the num- ber of participants in the research. Each individual's answer was read, coded, and then interpreted thematically. Themes were then grouped into relevant categories on the bases of theme essence (Dutton \& Dukerich, 1991).

Three themes emerged concerning ratings of brand distinctiveness. These themes were labeled brand image, distinct marketing practice, and personal pleasure. The primary reason indicated for ratings of brand distinctiveness was the image of the social responsibility of the brand (41.5\%) (e.g., "The brand stands out because it supports a cause and it is not purely profits"). Several participants (29.7\%) responded that the brand that engaged in CRM was distinct because other brands do not engage in corporate social responsibility (e.g., "Not many companies do that."). Some participants (18.1\%) indicated a feeling of pleasure as a reason for their ratings of brand distinctiveness (e.g., "When I can support a good cause while buying something I like, it stands out as a different shopping experience than normal."). On the other hand, a few participants (10.7\%) indicated that other characteristics of a brand (e.g., product quality) should be good in order for an apparel brand to stand out (e.g., "The brand would need to produce quality products while supporting the cause in order to really stand out.").

One major theme emerged concerning ratings of brand credibility. This primary reason identified for ratings of brand credibility was participant's trust in the brand as generated by the brand's CSR initiative (66.3\%) (e.g., "I can trust this type of brand because they don't think solely of themselves".). However, some participants (33.6\%) indicated they had doubts about who benefited from the donation. (e.g., "I can trust a brand after seeing where their donation actually ends up".)

Three themes emerged from participants' responses to the brand attractiveness: CSR image of a brand, participation in the cause support, and positive attitude toward the marketing program/message. Participants liked the brand due to the corporate social responsibility image of the brand $(41.7 \%)$. Another primary reason given as explanation for ratings of brand attractiveness centered on 
the opportunity to support a cause by purchasing a product (31.9\%) (e.g., "If I bought something from the brand and knew that the money will be used to help people in need, I would probably feel better about my purchase.”). Other participants (26.4\%) indicated they held a positive attitude toward the marketing program or message itself ("I like that the brand supports AIDS.").

In summary, participants responded that they developed a positive perception of the brand due to their ideas about how socially responsible the brand was and that the described CRM program enabled them to support a cause. These responses support the idea that brand images stemming from CRM strategies exert an important influence on consumer's ideas about brand distinctiveness, credibility, and attractiveness supporting the significant statistical relationships between these concepts.

\section{Discussion and Implications}

Based on Curra's-Pe'rez et al.(2009)'s conceptual model of consumer identification with a socially responsible company, we investigated the effect of CSR image of cause-related marketing efforts on consumer's identification and response to a brand within the context of fashion industry. Overall, the results were congruent with Curra's-Pe'rez et al.(2009)'s model. The results supported hypotheses of predictive relationships between CSR image, brand distinctiveness, brand attractiveness, $\mathrm{C}-\mathrm{C}$ identification, attitude toward the brand, and purchase intention. In addition, the inclusion of the concept of brand credibility enhanced the model by demonstrating the impact of another brand attribute on C-C identification. Thus, the proposed relationships between CRM, C-C identification, and positive consumer response can be applied to the context of fashion brands. Participants responses to questions asking them to indicate the "why" of their ratings of brand distinctiveness, credibility and attractiveness also supported the idea that the concepts influence each other in the hypothesized manner. Therefore, as Yoon et al.(2006) proposed, we can assume that the favoritism toward a socially responsible brand could allow our participants to meet two objectives: to project their personal identity through association with the socially responsible brand (e.g., C-C identification) and to reward the socially responsible brand by behavioral commitments (e.g., purchase intention).

From a theoretical standpoint, the contribution of this study was to extend prior work on CRM by investigating how C-C identification influences consumer's responses to CRM. This study also found that Curra's-Pe'rez et al.(2009)'s model that had been tested in the context of other industries (e.g., hygiene product industry) can be also applied to fashion businesses.

This study provided empirical evidence that a brand's engage- ment in CRM contributes to consumer's positive perceptual (e.g., perception of brand distinctiveness, credibility, and attractiveness), attitudinal (e.g., attitude toward the brand), and intended behavioral response (e.g., customer loyalty) toward the brand through C-C identification. Therefore, marketers can utilize cause-related marketing strategies and publicize their actual cause-support efforts as these efforts influence a brand's image. Also, given that participants responded to a brand positively as a result of their identification with a socially responsible brand, marketers could create advertising messages as part of CRM that stimulate consumer's association of their personality, values, and identity with those of the brand.

\section{Limitations and Suggestions for future study}

In this study we used a convenience sample of undergraduates. However, all age groups may be exposed to fashion brand's marketing activity. Thus, future researchers could investigate how other age groups perceive and respond to fashion brands' CRM initiatives. It is possible that some generations of consumers will respond more positively to this strategy than others. Second, this study used an arbitrary brand name and a single type of CRM, thus, it is possible that participants overestimated the given brand's CRM activity. To control for any overestimation effect of the stimuli, several versions of CRM types could be tested (e.g., RED campaign, Pink Ribbon campaign, anti-bullying campaign) using an experimental research design to assess effect sizes and scenario type. Third, fashion brands engage in a variety of CRM. The CRM for the US brand American Apparel, is to emphasize their antisweatshop policy relative to production. They include on their garment labels the following statement: "All of our 1500 employees, sewing and administrative alike, are paid fairly and have access to basic benefits like healthcare" (Kuczynski, 2005). Adidas, a German-based sports brand, also emphasizes the issue of global warming in the production of one of their apparel lines. (e.g., produce an eco-friendly apparel line). As other possible lines of future research, our research model could be applied to other types of CSR initiatives such as green marketing and anti-sweatshop campaigns to assess their impact and effectiveness.

Future researchers could also focus on the effect of CRM on consumer responses relative to different types of donation-based CRM. In case of transaction-based cause marketing, a cause is identified by the company, a purchase is made by the consumer, and then the company donates a percentage of the profits from the sale to support the cause. On the other hand, in sponsorship-linked marketing, a company donates to a social cause, tells their cus- 
tomers that they make a donation, and then hopes that customers will continue buying from them as a result of the way they do business (i.e., because they donate to social causes). Thus, under each type of donation-based CRM, consumer response could differ indicating some may be more effective than others.

Previous researchers have investigated the effect of CRM on consumers in the context of different industries (e.g., pharmaceutical industry, skin care company). Thus, future researchers could investigate whether consumer's response to CRM will differ based on the industry category. This would answer the question of whether more or less good behavior is expected based on what type of industry is making the donation? If the industry historically has high profit margins for example, do consumers expect more from companies in this industry than companies in an industry where profit margins are traditionally low?

\section{References}

Andrews, M., Luo, X., Fang, Z., \& Aspara, J. (2014). Cause marketing effectiveness and the moderating role of price discounts. Journal of Marketing, Advance online publication. DOI: http://dx.doi.org/ 10.1509/jm.14.0003.

Barone, M., Norman, A., \& Miyazaki, A. (2007). Consumer response to retailer use of cause-related marketing: is more fit better? Journal of Retailing, 83(4), 437-445.

Becker-Olsen, K., \& Hill, R. (2006). The impact of sponsor fit on brand equity: The case of nonprofit service providers. Journal of Academic Marking Science, 9(1), 73-83.

Bergami, M., \& Bagozzi, R. (2000). Self-categorization, affective commitment and group self-esteem as distinct aspects of social identity in the organization. The British Journal of Social Psychology, 39(4), 555-577.

Bhattacharya, C. B., \& Sen, S. (2003). Consumer-company identification: A framework for understanding consumers' relationships with companies. Journal of Marketing, 67(2), 76-88.

Bigné-Alcañiz, E., Currás-Pérez, R., Ruiz-Mafé, C., \& Sanz-Blas, S. (2010). Consumer behavioural intentions in cause-related marketing: The role of identification and social cause involvement. International Review on Public and Nonprofit Marketing, 7(2), 127-143.

Bloom, P. N., Hoeffler, S., Keller, K. L., \& Meza, C. E. B. (2012). How social-cause marketing affects consumer perceptions. Image.

Burns, D. J., Reid, J., Toncar, M., Anderson, C., \& Wells, C. (2008). The effect of gender on the motivation of members of Generation Y college students to volunteer. Journal of Nonprofit and Public Sector Marketing, 19(1), 99-118.

Byrne, B. (1998). Structural equation modeling with LISREL, PRELIS, and SIMPLIS. NJ: Lawrence Erlbaum Associates, Inc.

Carroll, A. (1991). The pyramid of corporate social responsibility: Toward the moral management of organizational stakeholders. Business Horizons, 34(4), 39-48.

Cornwell, T. B., \& Coote, L. V. (2005). Corporate sponsorship of a cause: The role of identification in purchase intent. Journal of Business Research, 58(3), 268-276.
Curra's-Pe'rez, R., Bigne'-Alcañiz, E., \& Alvarado-Herrera, A. (2009). The role of self-definitional principles in consumer identification with a socially responsible company. Journal of Business Ethics, 89(4), 547-564.

Dutton, J. E., \& Dukerich, J. M. (1991). Keeping an eye on the mirror: Image and identity in organizational adaptation. Academy of Management Journal, 34(3), 517-554.

Fornell, C. \& Larcker, D. F. (1981). Evaluating structural equation models with unobservable variables and measurement error. Journal of Marketing Research, 18(1), 39-50.

Groth, M. (2005). Customers as good soldiers: Examining citizenship behaviors in internet service deliveries. Journal of Management, $31(1), 7-27$.

Hair, J. F., Anderson, R. E., Tatham, R. L., \& Black, W. C. (1998). Multivariate Data Analysis (5th ed.). NJ: Pearson Prentice Hall.

Hong, S. Y., \& Rim, H. (2010). The influence of customer use of corporate websites: Corporate social responsibility, trust, and word-of-mouth communication. Public Relations Review, 36(4), 389-391.

Hyllegard, K. H., Ogle, J. P., Yan, R-N., \& Attmann, J. (2010). Exploring Gen Y responses to an apparel brand's use of causerelated marketing: Does message matter when it comes to support for the breast cancer cause? Clothing \& Textiles Research Journal, 28(1), 19-34.

Kim, E. G., \& Sung, H. (2011). A study of social responsibility and cultural marketing of Korean casual brands. Fashion \& Textile Research Journal, 13(2), .162-172.

Kim, G. S. (2007). AMOS 7.0 Analysis structural equation modeling. Seoul: Hannarae.

Kuczynski, A. (2005, June 2). Part cotton, part virtue, part come-on. New York Times. Retrieved from http://www.nytimes.com/2005/ 06/02/fashion/thursdaystyles/02critic.html?pagewanted=all\&_r=0

Kunda, Z. (1999). Social Cognition: Making Sense of People. Cambridge. MA: MIT Press.

Lee, J. I., \& Shin, S. Y. (2011). The influences of consumer behavior according to their perceived suitability toward the type of corporate social responsibility activities. Fashion \& Textile Research Journal, 13(6), 888-899.

Lii, Y. S., Wu, K. W., \& Ding, M. C. (2011). Doing good does good? Sustainable marketing of CSR and consumer evaluations. Corporate Social Responsibility and Environmental Management, 20(1), 15-28.

Mackenzie, S. B., \& Lutz, R. J. (1989). An empirical examination of attitude toward the Ad in an advertising pretest context. Journal of Marketing, 53(2), 48-65.

Marn, L., \& Ruiz, S. (2007). I need you too! Corporate identity attractiveness for consumers and the role of social responsibility. Journal of Business Ethics, 71(3), 245-260.

McWilliams. A., \& Siegel, D. (2001). Corporate social responsibility: A theory of the firm perspective, The Academy of Management Review, 26(1), 117-127.

Nan, X., \& Heo, K. (2007). Consumer response to corporate social responsibility (CSR) initiatives. Journal of Advertising, 36(2), 6374.

Newell, S. J., \& Goldsmith, R. E. (2001). The development of a scale to measure perceived corporate credibility. Journal of Business Research, 52(3), 235-247. 
Polonsky, M., \& Speed, R. (2001). Linking sponsorship and cause related marketing. Complementarities and conflicts. European Journal of Marketing, 35(11/12), 1361-1385.

Sen, S., \& Bhattacharya, B. (2001). Does doing good always lead to doing better? Consumer reactions to corporate social responsibility. Journal of Marketing Research, 38(2), 225-43.

Sirdeshmukh, D., Singh, J., \& Sabol, B. (2002). Consumer trust, value, and loyalty in relational exchanges. Journal of Marketing, 66(1), 15-37.

Tlin, E., \& Swait, J. (2004). Brand credibility and its role in brand choice and consideration. Journal of Consumer Research, 31(1), 191-199.

Van den Brink, D., Odekerken-Schröder, G., \& Pauwels, P. (2006). The effect of strategic and tactical cause-related marketing on consumers' brand loyalty. Journal of Consumer Marketing, 23(1), $15-25$.

Yoon, Y., Grhan-Canli, Z., \& Bozok, B. (2006). Drawing inferences about others on the basis of corporate associations. Journal of Academic Marketing Science, 34(2), 167-173.

Zhou, K. Z., \& Nakamoto, K. (2007). The effect of enhanced and unique features on new product preference: The moderating role of product familiarity. Journal of the Academy of Marketing Science, 35(1), 53-62.

(Received 23 September 2014; 1st Revised 9 October 2014; 2nd Revised 24 October 2014; Accepted 29 October 2014)

Copyright (C) 2014 (by) the authors. This article is an open access article distributed under the terms and conditions of the Creative Commons Attribution license (http://creativecommons.org/licenses/by/3.0/), which permits unrestricted use, distribution, and reproduction in any medium, provided the original work is properly cited. 